\title{
The Metamorphosis of the Spanish Inquisition, 1520-1648
}

Werner Thomas

\section{$1 \quad$ Introduction}

Seen in retrospect, few historians find it surprising that the Spanish Inquisition, founded in 1478 , lasted for more than $35^{\circ}$ years and was only suppressed in 1834. Ever since the 16th-century the Black Legend and its subsequent variants-including present-day versions ${ }^{1}$-have made use of the institution as an important element in their anti-Catholic, anti-Habsburg, and anti-Spanish propaganda campaigns. The image of an extremely powerful and efficient organization, that tortured and burnt thousands of innocent people, that was not subordinate to any other secular or ecclesiastical jurisdiction but its own, did not obey any other authority than the Inquisitor General's, and in whose hands kings and popes were mere puppets that carried out its orders, became widespread in Europe. ${ }^{2}$ From this point of view, its durability until the early 19th century was self-evident.

However, when the Catholic Kings set up the Inquisition in their kingdoms, it was not at all clear that they had a permanent institution in mind. ${ }^{3}$ Indeed, most medieval antecedents were conceived as emergency devices for outbursts of heresy that were restricted in time and space. Once the problem was under control, the inquisitors departed. ${ }^{4}$ But even if the Spanish Inquisition was meant to be a permanent tribunal from the beginning, it is still surprising that it survived the first fifty years of its existence, and in particular the span from 1500 to 1521 , which was a period of crisis that included regime changes, popular uprisings, and even open war. In fact, during these years the Inquisition was more than once on the verge of abolition.

1 See, for example, Paul Preston's The Spanish Holocaust: Inquisition and Extermination in Twentieth Century Spain (London: 2012), or Michael Robert's blog on the recent economic crisis in Spain, entitled 'Spain: the return of the Inquisition,' on https://thenextrecession .wordpress.com/2013/05/12/spain-the-return-of-the-inquisition/ (retrieved 28 May 2015).

2 Moreno Martínez, La invención, 125-142.

3 Kamen, The Spanish Inquisition, 46.

4 Peters, Inquisition, 44-74. 
Nonetheless, the Inquisition not only survived this turbulent period, but in the aftermath of the Revolt of the Comuneros it also managed to eliminate its political enemies. In the next forty years, important changes in its functioning were introduced in order to render it less vulnerable to future crises, and thus to secure its continued existence. Measures included the optimization of the institution's geographical configuration, the deepening of its embedding into local society, the reinforcement of its members' legal protection, and the establishment of its financial independence. Hence, between $15^{20}$ and 1560 the Inquisition managed to significantly strengthen its power base, and reinforce its position in Spanish society. In the years following, the system of social control was enhanced and techniques of socialization and stigmatization were brought to perfection. As a result, between 1560 and 1620 approximately, the institution became the cornerstone of the religious policy of the Spanish monarchy, and one of the driving forces of the confessionalization process in Spain.

The aim of the present chapter is to analyze the process that transformed the Inquisition from a poorly organized and at times widely-contested institution, almost exclusively obsessed by Judaism, into the post-Tridentine defender of Catholicism against all kinds of heresy and unbelief in Spain and abroad. It starts by briefly outlining the crises that almost led to the disappearance of the institution, and subsequently focuses on each of the components of the reform that consolidated its power. It further studies the evolution from a formal to an informal system of social control. Finally, it discusses the extension of its jurisdiction that was the result of its role in the confessionalization process.

By the beginning of the 16th century, the problem of the New Christians (conversos) in Spain, discussed in the preceding chapter, seemed more or less solved. In the two decades that followed the creation of the Spanish Inquisition in 1478 , Jewish converts to Christianity and their descendants who were accused of covertly adhering to the faith of their ancestors (judaizantes), were fiercely persecuted. As a supporting measure, the Catholic Kings expelled the Jews from their kingdoms in 1492, thus eliminating the social support network of the converts. Around 1500, the last clandestine synagogues were discovered and dismantled. ${ }^{5}$ Consequently, the number of convicted conversos decreased

5 García Cárcel \& Moreno Martínez, Inquisición, 206. 
spectacularly, and between 1504 and $15^{20}$ isolated nuclei of remaining judaizers were discovered only sporadically. ${ }^{6}$

Since the Inquisition was financed, at least during the first decades of its existence, by the confiscation of offender's properties, and, to a lesser extent, by the fines that were imposed on them, the sharp decline in the number of condemned judaizers had serious consequences at the organizational level. Inquisitorial districts were reorganized. While in 1495 the kingdom of Castile counted sixteen tribunals in its territory, by 1507 only seven were left. In Aragon the number of tribunals was reduced from six to four. ${ }^{7}$ Several super-districts were created, such as that of Valladolid, which from 1503 onward also included the former districts of Salamanca, Burgos, Avila, Segovia, and León, while the overall number of inquisitors was almost halved, thus reducing the operational performance of the institution. ${ }^{8}$

On top of those economic and organizational problems, the political crises that broke out from 1505 onward affected the position of the Inquisition in Spanish society even more. These crises were the result of the struggle between two political factions scrambling for power at court since the beginning of the reign of the Catholic Kings. The group surrounding Queen Isabel-the so called partido isabelino-consisted of the servants of her father that had supported her claims to the throne of Castile, members of the urban elites that served in her household or in the Castilian administration, and clergymen, mostly Observant Franciscans; many of them had converso roots, and they advocated a policy of persuasion and instruction vis-à-vis newly converted Christians. The court faction supporting King Ferdinand-the partido fernandino-included his Aragonese servants and his followers in Castile; most of them defended the Old Christian values and pled for coercion rather than persuasion in order to preserve the orthodoxy of the converts' faith. ${ }^{9}$ The three regime changes were the turning points in this struggle for power, and the Inquisition became a powerful weapon in it.

The first crisis began with the death of Queen Isabella in 1504. In the years before, the partido fernandino had slowly imposed itself, and by the end of the $15^{\text {th }}$ century it controlled most of the royal councils, including the Council of the Inquisition; firmly in the hands of the King's confidante Diego de Deza from 1498 onward. ${ }^{10}$ Once the fernandinos had acquired control over the Holy

\footnotetext{
6 Dedieu, L'administration, 238.

7 Dedieu \& Contreras, 'Geografía,' 40-45.

8 Martínez Millán, La hacienda, 259.

9 Martínez Millán, 'Las élites,' 103-167.

10 On Deza, see: José Martínez Millán, 'Deza Tavera, Diego,' in Prosperi, Dizionario, vol. 1, 473-474.
} 
Office, they started using it in order to eliminate their enemies in royal and city councils, and in ecclesiastical institutions. ${ }^{11}$ However, one of those campaignsthe persecutions conducted by inquisitor Diego Rodríguez de Lucero in Cordoba and Granada-got completely out of hand. Lucero made use of dubious interrogation techniques in order to obtain confessions, and sent hundreds of mostly innocent people, many of them isabelinos, to the stake. ${ }^{12} \mathrm{He}$ even tried to eliminate the archbishop of Granada, Hernando de Talavera, former confessor of the Queen, converso himself, who strongly opposed the creation of an inquisitorial tribunal in Granada. ${ }^{13}$ Protest was easily suppressed by the Inquisitor General, who had the support of the king himself. ${ }^{14}$

When Queen Isabella died, things changed. The families of the victims and the members of the city councils that were purged, joined the Castilian elites opposing Ferdinand's centralizing policy with the intention of removing the fernandinos from power. They approached the new government of Philip the Handsome in Brussels and urged him to suppress the Holy Office. ${ }^{15}$ Indeed, even before leaving the Netherlands, Philip ordered the suspension of all inquisition activities, and on his arrival in Spain, in the spring of 1506, the new King proposed to the Cortes of Valladolid that the Inquisitor General be deposed and abolition of the Council of the Inquisition. ${ }^{16}$ However, the death of the King in September 1506 interrupted any reform program. Philip's intervention did have one important consequence: as a reaction to his son-in-law's hostile attitude towards the Holy Tribunal, Ferdinand split it into two separate entities. Thus, from 1507 onward Castile and Aragon each had their own inquisition, their own council of the inquisition, and their own inquisitor general, a situation that persisted until 1528 , although the posts of inquisitor general were merged earlier, in $1517 .^{17}$

The second crisis started with the death of Ferdinand of Aragon in 1516. Again, the former isabelinos approached the new king, Charles of Luxemburg, at his court in Brussels, pleading for the suppression, or at least a thorough reform, of the Inquisition. Advised by Francisco Jiménez de Cisneros, regent of Spain in the absence of the king, Charles first decided not to change anything,

\footnotetext{
11 García Cárcel \& Moreno Martínez, Inquisición, 36-38.

12 García Cárcel \& Moreno Martínez, Inquisición, 37-38; Kamen, The Spanish Inquisition, 72. On Lucero, see: G. Civale, 'Rodríguez Lucero, Diego,' in Prosperi, Dizionario, vol. 3, 1336-1337.

13 On Talavera, see: A. González Polvillo, 'Talavera, Hernando de,' in Prosperi, Dizionario, vol. 3, 1556-1557.

14 García Cárcel \& Moreno Martínez, Inquisición, 38.

15 Martínez Millán, La Inquisición española, 71-72.

16 Martínez Millán, La Inquisición española, 74.

17 Kamen, The Spanish Inquisition, 139.
} 
but once in Spain the Cortes of Valladolid confronted him with their complaints about the Inquisition. ${ }^{18}$ As a result, he ordered his chancellor Jean le Sauvage to elaborate a reform program which included more rights of the defense and confiscation of property only after sentencing. Le Sauvage, however, died before concluding the project, and Adrian of Utrecht, the new inquisitor general, stopped the reform process. Conversos and isabelinos now joined the Revolt of the Comuneros, who included reform of the Inquisition in their list of demands. The rebels' defeat in 1521 also ended the hope of those who thought that the Inquisition could be suppressed. ${ }^{19}$

The third crisis was this time not the result of political instability. It started in $155^{8}$ when two Protestant movements were discovered in Valladolid, the capital, and Seville, the port connecting Spain with the Indies. ${ }^{20}$ The dimensions of each group, the fact that the vast majority of their members were Spaniards, their social status, and the completeness of the Protestant doctrine they believed in worried the authorities, in particular because the Inquisition, due to the economic crisis, was not in a position to react efficiently.

Inquisitor General Fernando de Valdés, who had fallen into disgrace and been sent away from court a few months earlier, seized the opportunity to regain his power, leading the extirpation of both movements with the full support of King Philip II and Pope Paul IV. ${ }^{21}$ At the same time, he issued a set of instructions that enhanced the operational capacity of the Inquisition, a process that was continued by his successors Diego de Espinoza and Gaspar de Quiroga. ${ }^{22}$

One of the first challenges of the Inquisition in post-Comunero Spain was undoubtedly the restoration and extension of its control over the territory it was supposed to keep under surveillance, an operation that was rendered more

18 Avilés Fernández, 'Motivos,' 181-182. On Cisneros, see: José Ignacio Pulido Serrano, 'Cisneros, Francisco Jiménez de,' in Prosperi, Dizionario, vol. 1, 334-335.

19 Gutiérrez Nieto, Juan Ignacio, 'Los conversos y el movimiento comunero,' Hispania 24 (1964): 237-261.

20 On the Valladolid and Sevilla trials, see Tomás López Muñoz, 'Siviglia, processi di' and 'Valladolid, processi di,' in Prosperi, Dizionario, vol. 3, 1442-1444 and 1643-1646.

21 On Valdés, see: Michel Boeglin, 'Valdés, Fernando de,' in Prosperi, Dizionario, vol. 3, 1622-1624.

22 González Novalín, El inquisidor general, vol. 1, Chapter 9; Martínez Millán, José, 'En busca de la ortodoxia: el inquisidor general Diego de Espinosa,' in La corte de Felipe II, (ed.) José Martínez Millán (Madrid, 1994), 189-228. 
difficult by the formation of super-districts at the beginning of the 16th century. New districts were organized to overcome the deficiencies in the geographical configuration of the tribunal. From 1520 onward, the Council of the Inquisition made several attempts to create a tribunal in Galicia-a kingdom that formerly belonged to the district of Valladolid-in order to address the problem of the immigration of Portuguese conversos escaping persecution by the tribunal of Coimbra, although by 1532 it ceased its efforts as a result of the resistance of local authorities. ${ }^{23}$ Simultaneously, the tribunal of Cuenca, founded in 1510 as a branch of the district of Murcia, was separated from the latter. In 1526, the kingdom of Granada was separated from the district of Cordoba and got its own tribunal. Except for the independence of the tribunal of the Canary Islands in 1567 , the final creation of the tribunal of Galicia in 1574, and the establishment of the tribunal of Madrid in 1647, no further changes were made to the Inquisition's geographical organization in Spain. ${ }^{24}$

At the same time, recently created tribunals were activated. In 1524, a new inquisitor was appointed to the district of the Canary Islands, created in 1507 and put under the authority of the tribunal of Seville, but almost inactive since beginning; only nine individuals were tried for heresy prior to $15^{20}$. In contrast, between 1524 and 1530 the number of detentions immediately rose to $181 .^{25}$ The tribunal of Navarre, founded in 1513 as a branch of the district of Zaragoza, but almost inactive until $15^{21}$ as a result of the threat of a French invasion, was added to the district of Calahorra and started functioning normally. ${ }^{26}$

Finally, several bishoprics were swapped between districts, allowing a more efficient control of the territory from one central point. By 1540, this process had come to an end. ${ }^{27}$ Within every district the seat of each tribunal became fixed. While before, inquisitors travelled from one town to another within their district, taking up residence in different locations and subsequently organizing autos-da-fé on the spot, all judicial activity-including public executions-was thereafter concentrated in the district's capital. In order to enhance surveillance of the population living outside the capital, the system of regular visits to the towns and villages of the district (visitas), already established in 1498, was intensified. Every tribunal was obliged to organize at least one visit annually with a duration of several months, and if the workload allowed the absence in

23 Contreras, El Santo Oficio, 23-26.

24 Contreras \& Dedieu, 'Estructuras geográficas,' 9-13.

25 Andrés Acosta González, 'La Inquisición en Canarias durante el siglo XVI (una aproximación estadística),' Anuario de estudios atlánticos, 32 (1986): 129-193 (in particular 137138, 188, 191).

26 Contreras \& Dedieu, 'Estructuras geográficas,' 31-33.

27 Dedieu \& Contreras, 'Estructuras geográficas,' 9-13. 
the district capital of the two inquisitors, they were both supposed to engage in tours of inspection. ${ }^{28}$ Especially from 1525 onward, visitas became more frequent and longer-lasting, stimulating denunciations, which resulted in more trials. $^{29}$

Parallel to the reorganization of its geographical infrastructure, the Inquisition expanded the network of so called familiares in order to embed it deeper into local society. The position of familiar already existed in the medieval inquisition. Familiares were laymen that assisted the inquisitors and their local officials performing such duties as transferring arrested persons to the prison of the Inquisition, and accompanying local officials when they proclaimed inquisitorial edicts, interrogated witnesses, or confiscated property. They also served as a kind of personal guard for the inquisitors during the visitas. Finally, they played an important role during autos-da-fé, participating in the processions held at those occasions, and in particular escorting the convicts to the scaffold. ${ }^{30}$

However, any other judicial authority was able to perform these tasks. Moreover, royal and inquisitorial regulations obliged any office holder to assist the Inquisition and its officials whenever they asked for it. The main benefit of the body of familiares lay therefore in its capacity to act as an intermediary structure between the institution and local society. This explains why the number of familiares in Aragon was from the beginning much higher than in Castile: popular resistance against the introduction of the Inquisition in Aragon had indeed been much more significant. ${ }^{31}$ Up to the 17 th century, most familiares were not recruited from the ranks of the nobility, the gentry nor the high clergy, but from among the middle strata of the social system: rich farmers on the countryside, artisans and merchants in the cities. The underlying idea was that when more respectable members of rural and urban society visibly assisted the Inquisition as familiares, acceptance of the institution in local society would increase. ${ }^{32}$

As incentives for someone to become a familiar in their town or village, the position, although non-remunerated, included several privileges, such as the right to use arms, exemptions from taxes and military services, and the right to hold public office. ${ }^{33}$ Above all, the appointment as familiar was a public

28 Peyre, 'L'Inquisition,' 55-58; Kamen, The Spanish Inquisition, 179-181.

29 Peyre, 'Linquisition,' 55-65; Dedieu, 'Les Inquisiteurs,' 236-237.

30 Cerrillo Bonet, 'Aproximación,' 156-157; Bethencourt, The Spanish Inquisition, 165-166.

31 Cerrillo Bonet, 'Aproximación,' 143.

32 Contreras, 'Clientelismo,' 51-69; López Vela, 'Sociología,' 806-820, 828-832.

33 García Cárcel \& Moreno Martínez, Inquisición, 138-142; Cerrillo Bonet, 'Aproximación,' $150-156$. 
recognition of the family's status of Old Christians, since being of 'purity of blood' was one of the conditions required from candidates. Curiously, candidates in Castile attached greater importance to the certificate of purity of blood, while their Aragonese counterparts gave priority to the privileges that went with the position. ${ }^{34}$

Becoming a familiar thus gave access to a well-defined social group with a particular social status that increased the honor and prestige of the officeholder and his family. In particular those members of the rural and urban elites who were unable to join the nobility, welcomed this alternative route to social promotion in a strictly hierarchical society. Only in the 17 th century did the Inquisition, especially in Castile, start to admit noblemen to the post of familiar, thus strengthening its ties with the traditional elite. ${ }^{35}$

From the very beginning, the expansion of the network of familiares was strongly contested by civil authorities, in particular the Cortes, the municipal councils, and the other courts of justice. They opposed the creation of a social group that would threaten the existing social order and was almost completely outside the reach of any other jurisdiction but the Inquisition's. In the aftermath of the death of Queen Isabel, many abuses by familiares were reported, the civil courts being powerless to stop them, while the Inquisition itself did not punish the perpetrators. ${ }^{36}$ Between 1510 and 1520 several attempts were made to impose a maximum number of familiares in each city, in keeping with the agreement made at the Cortes of Monzón in 1512 the most important of that period, but which was hardly respected by the Inquisition. ${ }^{37}$

In spite of the many protests, immediately after the defeat of the Comuneros the number of familiares started to rise spectacularly. ${ }^{38}$ Cities such as Barcelona (30 familiares in 1530, 79 in 1568), Valencia (25 familiares in 1501, 57 in 1568), or Cordoba (already 78 familiares in 1544 ) are striking examples. ${ }^{39}$ Most of the newly appointed familiares resided in urban centers; only Valencia's coastal regions-mainly Old Christian villages-were also covered by the network. Before $155^{\circ}$, ten to fifteen per cent of the familiares were located in the district capitals, and the others were spread over the other towns; hardly any resided in small villages. ${ }^{40}$ It seems clear that in the years following the political crises,

\footnotetext{
34 López Vela, 'Las estructuras,' 202, 205.

35 Kamen, The Spanish Inquisition, 147; Bethencourt, The Inquisition, 166-167.

36 Contreras, 'Clientelismo,' 57.

37 Kamen, The Spanish Inquisition, 147.

38 Bennassar, L'Inquisition, 96-97; Martínez Millán, La Inquisición, 179.

39 Contreras, 'La infraestructura,' 139; Bennassar, L'inquisition, 96-97.

40 García Cárcel \& Moreno Martínez, Inquisición, 138-139.
} 
the Inquisition wanted to connect with local, mostly urban elites in order to regain the support it had lost during the Revolt of the Comuneros.

As the number of familiares increased, protest swelled. The Cortes of Valencia waited until 1552 to ask for a reduction of their numbers and a restriction of their privileges, but the Cortes of Castile had already presented a similar proposal in 1525, and the Cortes of Catalonia raised their objections during their assemblies of $1533,1537,1542,1547$, and $155^{2} \cdot{ }^{41}$ As a result, in 1543 the Council of the Inquisition ordered the tribunals to reduce their auxiliary forces. ${ }^{42} \mathrm{In}$ the 1550 os agreements (concordias) were made between the Crown and the Inquisition in order to limit the number of familiares in each kingdom, and to establish their distribution across the towns and villages of each district; this was the case for Castile in 1553, Valencia in 1554, and Aragon and Catalonia in 1568. At the same time the privileges of the familiares were reduced, especially in Castile, where there was less need for intermediaries. ${ }^{43}$

However, what appears to be an intent to limit the Inquisition's local power and influence, was in fact a confirmation. The numbers mentioned in the concordias were very generously calculated; many of the towns and villages had not even reached their quota at the time of agreement. ${ }^{44}$ Moreover, by mentioning the number and allocation of familiares, the concordias also formalized, stabilized and even extended the network of the Inquisition in the districts. ${ }^{45}$ In fact, during the second half of the 16 th century, the familiares were much better distributed over the territory. From the 1560 s onward, their presence in the countryside was much more outspoken, and the number of villages and small towns where at least one familiar resided, increased significantly in almost every district. ${ }^{46}$ On top of this, local tribunals did not respect the quota established by the concordias, and the number of familiares kept growing during the second half of the century. Around 1620, between 10,000 and 12,000 people were connected to the inquisitorial system as remunerated and non-remunerated officials, most of them familiares ${ }^{47}$ Only when Philip IV started annulling privileges in the 1640 s, in particular the exemption from taxes and war contributions, did the period of growth come to an end. ${ }^{48}$

\footnotetext{
41 García Cárcel, Herejía, 140-141; Escudero, Estudios sobre la Inquisición, 306.

42 Cerrillo Cruz, 'Aproximación,' 145.

43 López Vela, 'Las estructuras,' 204-205.

44 Dedieu, L'administration, 192; Kamen, The Spanish Inquisition, 146-147.

45 López Vela, 'Sociología,' 8o8-810.

46 García Cárcel \& Moreno Martínez, Inquisición, 138-139.

47 López Vela, 'Las estructuras,' 193.

48 López Vela, 'Sociología,' 820-822; Martínez Millán, La Inquisición, 179-186.
} 
A third method to reestablish the authority of the Inquisition was the extension of the papal privilege of immunity (fuero inquisitorial) to all members of the institution. This privilege had been developed in medieval canon law, and was the consequence of the institution's competence, delegated by the pope, to override, when combating heresy, any privilege of any social group, including the nobility and the clergy, or any political entity, secular as well as ecclesiastical, and to act anywhere the Inquisition was installed. In order to apply this competence, canon law granted the inquisitors and their closest collaborators the privilege of complete immunity from any other jurisdiction and forbade any authority or individual to obstruct their work. ${ }^{49}$ In that way, sabotaging the Inquisition's actions by arresting its officials became impossible.

When the Iberian inquisitions were created, that privilege was given to the Spanish inquisitors, and the pope even delegated his authority over them to the inquisitors general of Castile and Aragon. From then onward, inquisitors could only be prosecuted by the Inquisitor General. The other officials of the Inquisition obtained the privilege that they could only be judged by the tribunals of Inquisition itself, in criminal as well as civil cases. Appeals were brought before the Council of the Inquisition. ${ }^{50}$

The privilege of immunity clearly infringed on the privileges and customary law of the Iberian principalities. It soon became one of the central conflicts between the Inquisition, the Cortes of Castile and Aragon, and municipal authorities. The definition of 'official of the Inquisition' in particular gave rise to disputes. Canon law did not specify whether minor offices such as secretaries and, above all, familiares, also enjoyed the benefits of the fuero. The Cortes, especially those of Aragon, soon denounced the abuses of the privilege by familiares in order to avoid prosecution in all kinds of lawsuits. In 1512, the Cortes of Monzón restricted the privileges of the familiares in the Crown of Aragon, and in 1514 the distinction between remunerated officials, non-remunerated officials, and familiares was introduced. The latter were excluded from the privilege of immunity when they were accused in criminal cases. ${ }^{51}$

In the years following the defeat of the Comuneros, the situation got out of balance. Not only did the number of familiares increase, the misuse they made of their privileges grew. The Inquisition as an institution strove for equal treatment of all of its members, including the familiares, and thus, for the application of the privilege in all cases. Local inquisitors clearly safeguarded their familiares by allowing them the judicial protection of the privilege in all cases,

\footnotetext{
49 López Vela, 'Las estructuras,' 192-226; Cerrillo Cruz, 'Aproximación,' 142-143.

$50 \quad$ López Vela, 'Las estructuras,' 195.

51 López Vela, 'Las estructuras,' 199-201.
} 
including criminal lawsuits. ${ }^{52}$ However, in Castile popular protest encouraged Charles v to annihilate the immunity of the familiares from 1545 onward. When the king and the Inquisition reached a final solution in 1553, the agreement established a clear distinction between regular officials and familiares. The latter lost their immunity in all civil cases and when perpetrators in criminal cases. In Aragon, on the contrary, the subsequent concordias restricted their number, but left their privileges for the most part intact. ${ }^{53}$

Hence, the Inquisition's strategy to protect all of its members granting them judicial immunity, thus reinforcing the position of the institution in local society, only partially succeeded. On the other hand, in 1515 the Holy Office obtained from Pope Leo $\mathrm{x}$ the jurisdiction to proceed against anyone who physically attacked or acted against inquisition officials. However, persecution only started after the Revolt of the Comuneros. From 1540 onward, obstruction of the Holy Office began to account for ten per cent of all cases, and even for 20 per cent in the district of Toledo. In 1569, the Inquisition reinforced its position when it obtained from Pope Pius V the extension of the 1515 motu proprio, allowing inquisitors to punish anybody attacking physically an inquisition official or obstructing their work, with the same penalties as the heretics themselves, including death at the stake. ${ }^{54}$ Apart from using physical and verbal violence, violating inquisition privileges, and hindering inquisitorial procedures, obstruction of the Holy Office also included hiding or advising heretics, thus avoiding their arrest and conviction, and it would continue appearing in the statistics of the Holy Office. The number of people convicted for obstruction would only decrease during the first decades of the 17 th century. ${ }^{55}$

Finally, in the course of the 16th century the Inquisition successfully created a solid financial basis making the institution economically independent of the royal administration. From the beginning, the Holy Office financed its organization and activities with the revenues from fines and confiscations of convicted persons, thus following the example of medieval antecedents. At least during the first decades of its existence, the Inquisition's collectors were obliged to give account of their activities to the royal treasury. ${ }^{56}$ This arrangement caused many complaints to come from conversos and Old Christians alike, who considered the use of confiscated property to pay the wages of the tribunal's staff to be an open invitation to fraud. They also opposed the fact

\footnotetext{
52 López Vela, 'Las estructuras,' 201.

53 Cerrillo Cruz, 'Aproximación,' 145.

54 López Vela, 'Las estructuras,' 198.

55 Dedieu, 'Les quatre temps,' 23.

56 Martínez Millán, La Inquisición española, 187-189.
} 
that confiscation-technically seizure-took place not once the accused was convicted, but from the moment of arrest. ${ }^{57}$

These objections were repeated again and again, and induced the enemies of the Inquisition to believe that the Holy Office condemned rich conversos on the basis of false accusations, only to be able to confiscate their property. Jean le Sauvage's 1518 project for reform of the Inquisition therefore included measures to prevent inquisitors from being paid with confiscation proceeds, but it was never put in practice. Later on, the comuneros formulated similar demands. ${ }^{58}$ Subsequently, the Cortes repeatedly became the voice of those who insisted on the reform of the financial structures of the Inquisition. In Castile, for example, the Cortes presented their complaints about the matter to the king during their assemblies of $1525,1537,1538,1548$, and 1555 , although with no result. ${ }^{59}$

Paradoxically, resistance by the Cortes, the royal courts of justice, and the Spanish church during this period also impeded the implementation of an alternative way of funding the Inquisition's activities, that would remove suspicions of conflict of interests resulting from the use of fines and confiscations. In 1501-with precedents in 1486 and 1494-Pope Alexander VI Borgia granted the Holy Office the right to use the revenues of one canonry of each metropolitan, cathedral, and collegiate church in Spain in order to finance the wages of its personnel. Concretely, inquisitors and prosecutors were to be appointed to the first vacancy to be filled in any of these chapters located within their district. However, bishops and chapters resisted from the beginning, using the argument that canons had to take up residence to receive their benefices, which, of course, inquisitors were never able to do. The 1501 privilege fell into disuse, and attempts by Charles V in 1518 and 1524 to obtain additional papal confirmation were unsuccessful. On the other hand, the frequent periods of absence of the emperor and public animosity prevented the Inquisition from insisting on its application. At the same time, fines and confiscations fell sharply and confronted the institution with an almost continuous deficit, with wages not being paid for long periods. ${ }^{60}$

The financial crisis of the Inquisition came to a head with the state bankruptcy of 1557. The recently enthroned King Philip II urged his ambassador in Rome to start negotiations with the pope. The discovery of the Protestant movements in Valladolid and Seville motivated Paul IV to act swiftly. On 7

\footnotetext{
57 Kamen, The Spanish Inquisition, 75-78, 149-151.

58 Thomas, La represión, 24-25, 32-33.

59 Manuel Colmeiro (ed.), Cortes de los antiguos Reinos de León y de Castilla (Madrid, 18831884), Chapter XxIv, passim; Avilés Fernández, 'Motivos,' 165-192.

6o Martínez Millán, La hacienda, 99-106.
} 
January 1559 he issued a papal bull confirming the 1501 privilege. This time, the Inquisition did not fail to put the privilege into practice, and already on 20 January it incorporated its first canonry. Resistance of bishops and chapters persisted for some years, but with the support of the king they were finally forced to obey. ${ }^{61}$

The incorporation of the canonries into the financial structures of the Inquisition gave local tribunals a high degree of economic autonomy. In order to better administer their revenues, the position of contador general, the central accountant at the level of the Council, was abolished and his competences were shifted to the newly created contadores of each tribunal. An important side effect of this restructuring was the almost complete loss of control of the Council over the finances of the local tribunals. They decided almost autonomously on their expenses, although they had to report annually on their financial situation and transfer the surplus to the Council in order to redistribute it among less wealthy tribunals. ${ }^{62}$

This economic autonomy might explain why in the second half of the 16 th century, the position of inquisitors in local society was so much stronger than in the decades before, leading to much more effective and determined persecution of heterodoxy. While before 1560 , tribunals, for example, sometimes abandoned the idea of organizing a public auto-da-fé because of lack of money, thus reducing the Inquisition's public visibility and representation in society, from 1560 onward they were able to publicly display the power of the Holy Office through these annual manifestations of the struggle against heresy, and to turn them into a powerful socialization mechanism. ${ }^{63}$ The inquisitors themselves, who for years could not afford to maintain a lifestyle in accordance with their authority and position in society, were finally enabled to express the Holy Office's power through their outward appearance. ${ }^{64}$

The importance that the Inquisition increasingly attached to its public appearance, to its presence in all corners of the Iberian Peninsula, and to the dignity of its members, was a symptom of another development that occurred in the

\footnotetext{
61 Martínez Millán, La hacienda, 106-112, 116-123.

62 Martínez Millán, La Inquisición española, 190-193.

63 Dedieu, L'administration, 214.

64 Martínez Millán, La hacienda, 108.

65 I define 'social control' as the enforcement of conformity to rules, norms and values by society upon its members, either by coercion (the formal means of social control) or by socialization (the informal means of social control).
} 
course of the 16th century. From being essentially an instrument of coercion, the Holy Office evolved into an instrument of socialization, and thus became a perfect tool of the confessionalization process in the hands of the Spanish monarch. By the end of the century, the Inquisition, apart from persecuting heresy, contributed heavily to the reproduction of the Spanish monarchy's religious model by passing on its values from one generation to another. In order to successfully take on this task, changes in its functioning were needed.

In the first decades of its existence, the Inquisition almost exclusively concentrated on conversos. In fact, between 1478 and 1520 judaizers accounted for more than 90 per cent of all convicts. ${ }^{66}$ Converso origins were sometimes difficult to hide. Although social integration of conversos was in many cases seamless, the collective memory of local communities commonly contained the names of the families of New Christian lineage. Many of them, as their Jewish ancestors, lived in specific cities and villages, and within these, in specific neighborhoods. They generally only occupied professions that were permitted to New Christians. Some of them had preserved cultural elements such as diet or habits of dress, language, or hygiene routine. ${ }^{67}$ In short, they were rather easily recognizable, which facilitated the control over this segment of society that inquisitors and Old Christians considered as more susceptible to apostasy.

In order to trace deviants among the converso population, the Inquisition mainly made use of two techniques: self-incrimination of what could be called first offenders, and surveillance of convicted persons. Self-incrimination was stimulated by the edict of grace (edicto de gracia). ${ }^{68}$ This document, based on medieval antecedents, encouraged deviants to present themselves to the Inquisition. The text concentrated on judaizers, although after 1502 it sometimes aimed at New Christians of Moorish descent (moriscos) as well. ${ }^{69}$ Every time an inquisitor inspected a town or village, he would read the edict of grace during mass in the parish church, and subsequently proclaim a 'period of grace,' in general 30 to 40 days, during which offenders could confess their crimes of heresy spontaneously without running the risk of being condemned to the death penalty, imprisonment, or confiscation of their property. They were then interrogated in order to ascertain the nature of their crimes and to identify

\footnotetext{
66 Kamen, The Spanish Inquisition, 57.

67 Bordes García, 'Los primeros edictos,' 125-126.

68 On the different edicts of the Spanish Inquisition, see: Andrea del Col, 'Editto,' in Prosperi, Dizionario, vol. 2, 529-530.

69 Bethencourt, The Inquisition, 184.
} 
their accomplices or any other suspects that had not appeared of their own volition. ${ }^{70}$

Edicts of grace thus had the potential to cause a snowballing of new accusations and arrests. Almost all regular trials during the first stage of inquisitorial persecution originated from accusations uttered by self-incriminating individuals. Nevertheless, it is believed that most judaizers preferred to trust the inquisitor's promise to be lenient, rather than to run the risk of being denounced by fellow offenders. ${ }^{71}$ In any case, during the first decades of the Inquisition, the edicts of grace were highly effective, producing several thousand self-incriminations: 1200 in Valencia between 1482 and 1488, $5^{221}$ in Toledo between 1485 and 1500, and 301 in Barcelona between 1488 and $1495 \cdot{ }^{72}$

Once tried, the Inquisition put the convicted judaizers under surveillance. The most important instrument in this respect was the sambenito, a penitential garment already used by the medieval inquisitions that allowed formal and informal social control. The reconciled had to wear it over their clothes every time they left their homes. ${ }^{73}$ Hence, they were identifiable as convicted heretics at all times and everywhere, and their doings and goings were easily monitorable. On some occasions, the Inquisition made use of special edicts directed towards the convict's offspring. In 1487, for example, the tribunal of Valencia issued an edict of grace in order to investigate Jewish practices among all children older than eleven of all judaizers that had been convicted as the result of earlier edicts of grace. ${ }^{74}$

The visitas al distrito, which have been discussed earlier, combined both techniques. On their tour through the district, inquisitors would proclaim the edict of grace in every town and village they visited, thus stimulating selfincrimination among local offenders. However, when one takes a look at the itineraries they usually followed, it becomes clear that many times they were directed towards those areas of the district where there were communities of conversos or, at a later stage, other focuses of apostasy, and that they were thus designed to inspect settlements that were considered potentially dangerous. ${ }^{75}$

In short, by 1500 the Inquisition had installed a system of direct social control, based on self-incrimination and denunciations of offenders by their

70 Pérez Villanueva \& Escandell Bonet, Historia, vol. 1, 196; Jiménez Monteserín, Introducción, 86-89.

71 Kamen, The Spanish Inquisition, 57-58.

72 Bordes García, 'Los primeros edictos,' 140; Kamen, The Spanish Inquisition, 174-175; Bethencourt, The Inquisition, 183.

73 Kamen, The Spanish Inquisition, 200.

74 Bordes García, 'Los primeros edictos,' 128.

75 Thomas, Los protestantes, 17-18. 
accomplices. Testimonies of the deviants themselves lay at the root of most trials, and surveillance of the convicted was in hands of the inquisitors. In the course of the 16th century, this system was slowly transformed into a system in which informal or indirect control prevailed and deviance was not so much traced by the Inquisition itself, but was brought to the tribunals by outsiders, not the offenders themselves or their accomplices, but witnesses of the deviant behavior. Surveillance shifted to the faithful, while the Inquisition provided the structures that facilitated denunciations. By 1600 this process had come to an end.

The first step of this evolution was probably the substitution of the edicts of grace by edicts of faith from 1500 onward. ${ }^{76}$ As was the case with the edicts of grace, edicts of faith were proclaimed at the arrival of the visiting inquisitors everywhere along their itinerary. Apart from that, they were also published annually by the inquisitors in the capital of the district. In time, however, edicts of faith became a fixed part of religious life in any village or town of the inquisitorial districts. Every year they were read in every parish churches of all communities with more than 300 inhabitants. ${ }^{77}$ Compared to the edicts of grace, edicts of faith were much more structured documents, and also contained a detailed list of heresies. On the other hand, the edicts of faith omitted the period of grace that offered lenience to self-incriminators. ${ }^{78}$ However, the most important distinction between both documents was the completely different focus: while edicts of grace aimed at self-incrimination, stimulating offenders to report themselves and their accomplices, the edicts of faith stressed denunciation of heretical beliefs, words or deeds committed by others. ${ }^{79}$ For this reason they were read during Lent, to coincide with the period during which the faithful were supposed to examine their consciences in view of their annual confession. ${ }^{80}$ Being aware of heretical beliefs, words or deeds and not consciously reporting them precluded the chance of absolution. Thus, the edicts

76 After 1500, edicts of grace were only used in the campaign against the moriscos of Aragon (1566) and Granada (1571-1597), against witchcraft in the Basque country (1610-1611), and against the spiritualist movement of the alumbrados (1623). Cf. Bethencourt, The Inquisition, 184-186.

77 Jiménez Monteserín, Introducción, 292 (cap. VI), 536-537.

78 Alicia Gojman Goldberg and Luis Manuel Martínez Escutia, 'La función del Edicto de Fe en el proceso inquisitorial,' in Memoria del III Congreso de historia del derecho mexicano (1983), (ed.) José Luis Soberanes Fernández (Mexico, 1984), 261-280; Villa Calleja, 'La oportunidad,' 301-319.

79 Jiménez Monteserín, Introducción, 503-531.

8o Villa Callejo, 'La oportunidad,' 301-333. 
were a strong stimulus to denounce any deviant behavior, which increased their effectiveness.

From the beginning of the $17^{\text {th }}$ century onward, the proclamation of the edict of faith was followed by the reading of the edict of anathema. The publication of this edict usually took place six days after the edict of faith, on the day the period allowed for the denunciation of deviants expired. The edict of anathema declared major excommunication for anyone who was aware of deviant practices and beliefs but did not denounce them. ${ }^{81}$ This put heretics and witnesses of heretical behavior on the same level, excluding them both from the community of the faithful. In order to terrify people even more, the edicts contained a series of terrible curses, threatening those who neglected their Christian duties with death, diseases, infertility, starvation, crop failure, blindness, robbery et cetera. ${ }^{82}$ And although major excommunication was an existing practice, the edict itself and the ceremony surrounding its proclamation were completely new; in fact only the Spanish Inquisition applied them. ${ }^{83}$

The edicts of faith and anathema stimulating people to report heretical behavior became important ingredients in the Inquisition's system of indirect social control during the 16th century. Simultaneously, the institution created new structures in order to facilitate and act upon denunciations. In 1558, permanent checkpoints were established in the country's main ports; they were to inspect incoming ships and to prevent the importing of forbidden literature. In 1574, the tribunal of Santiago was created in order to relieve the inquisitors of Valladolid and improve control over Galicia. From 1580 onward, the number of inquisitors attached to each district was increased from two to three, enhancing the tribunal's capacity to cope with larger amounts of trials. ${ }^{84}$

The creation of a network of commissioners (comisarios) was undoubtedly the most important new structure that the Inquisition introduced from the early 1550 os onward.

In the late 1550 s and early 1560 s the network expanded rapidly, becoming even more dense in the first half of the 17 th century. By then it covered a much larger territory in most districts than that of the familiares, and it also incorporated an extensive part of the countryside. ${ }^{85}$ Commissioners were members of the clergy-in general parish priests-that assisted the inquisitors on the spot. In popular literature, they are sometimes called the spies of the Inquisition in

\footnotetext{
81 Bethencourt, The Inquisition, 200-204.

82 Jiménez Monteserín, Introducción, 531-535.

83 Bethencourt, The Inquisition, 200-201.

84 Bethencourt, The Inquisition, 230, 240.

85 Bethencourt, The Inquisition, 81-82.
} 
the provinces. Of course, they were not: while the efficiency of a spy depends largely on his anonymity and capacity to operate undercover, commissioners acted publicly as agents of the Inquisition, being an extension of the district tribunal. None of the instructions issued by the Council of the Inquisition mentions any guidelines for active social control. ${ }^{86}$ Instead, they were a kind of auxiliary force: they arrested suspects, interrogated witnesses, conducted the investigations that were part of the procedure for obtaining the certificate of purity of blood, assisted in the confiscation of property, inspected local libraries and-if they were appointed to port towns-the cargo of incoming ships, supervised the familiares, et cetera. ${ }^{87}$ By so doing, they took work off the inquisitors' shoulders, allowing them to concentrate on administering justice, and thus helped increase the tribunals' capacity.

Above all, the presence of commissioners even in remote parts of the districts facilitated denunciations. For many inhabitants of the villages and towns in the countryside, that they could report a crime of heresy to the inquisitors in person was not at all obvious: they might have to travel for hours or even days to the district capital; they might have to abandon their job for several days and might possibly suffer a loss of income; their absence in the village might be difficult to explain, reducing the chances of their statement remaining anonymous; and finally, they would have to confront the inquisitors, who for most people were distant and severe judges. By contrast, the presence of a commissioner nearby eliminated all of these objections. ${ }^{88}$ The improved accessibility of the inquisitorial authorities translated almost immediately into a significant rise of denunciations. In the district of Cuenca, for example, the number of trials doubled in the years after $1560 .{ }^{89}$

Looking at the results of implementing the system of commissioners, it is probably not a coincidence that in the same period the inquisitorial visits to the districts fell in disuse. Visits were time consuming and very unpopular among the inquisitors themselves. More important, they became less effective once heresy was no longer located in particular towns and villages that had been visited over and over again (as was the case of judaizers and moriscos), but might be found anywhere in the district (in the case of Protestantism or blasphemy). From 1560 onward, there was a tendency to shorten the time inquisitors spent on visiting their district. In 1567 , the number of visits was officially reduced to one annually, and by 1580 most tribunals organized even less

86 Cf. the 1607 instructions published by Jiménez Monteserín, Introducción, 339-360.

87 Bethencourt, The Inquisition, 81-82.

88 Thomas, Los protestantes, 64-65.

89 Nalle, God in La Mancha, 59. 
than one visit every year. Between 1580 and 1630 , for example, the tribunal of Toledo undertook 20 inspection visits, and periods of annual visits (1581-1583, 1604-1607) alternated with many years of no visits at all (1597-1603, 1622-1629). After 1630 , visits ceased completely. ${ }^{90}$

Creating the infrastructure to facilitate denunciations and enhancing the capacity of the tribunal to deal with large amounts of cases was, of course, not sufficient in order to motivate people to report deviant behavior. In the past, historians, probably under the influence of the Black Legend, were convinced that the Inquisition stimulated denunciations by what Bartolomé Bennassar has called a 'pedagogy of fear' (pédagogie de la peur). ${ }^{91}$ Not so much by torturing and condemning deviants to the stake, but by keeping the inquisitorial procedure a secret, driving the convicts into poverty and social isolation, and perpetuating the memory of their infamy, the Inquisition created a climate of fear that motivated people to report heresy in order to escape prosecution themselves. The appearance of the edict of anathema seems to confirm this. This interpretation is based on the perception of 16th-century Spain as a society of dissension: most subjects of the king disagreed with the Holy Office's activities, but they obeyed, mainly because of fear.

However, analysis of petitions submitted by the Cortes and by municipal authorities, popular resistance to inquisitorial procedures, verbal and physical attacks of the Inquisition's personnel, assaults on inquisition buildings, and declarations by witnesses and perpetrators during inquisitorial trials has shown that Old Christians at least did not fear the Inquisition and its officials at all. It rather appears that they approved the activity of the Holy Office because they endorsed the norms and values of Spanish Christianity and wanted the inquisitors to preserve them. In other words, 16th-century Spain was a society dominated to a considerable extent by consensus, and this environment stimulated denunciations of deviant behavior. ${ }^{92}$

In this respect, socialization techniques became increasingly important, especially when the Inquisition started to persecute groups of deviants other than conversos and moriscos. Internalization of norms and values was one of the goals that was frequently sought. The acceptance of this set of norms and

\footnotetext{
90 Dedieu, 'Les Inquisiteurs,' 236-237, 241-242; Bethencourt, The Inquisition, 73, 237-241.

91 Bennassar, L'Inquisition espagnole, 105-141.

92 Thomas, Los protestantes, $12-30$.
} 
values was promoted by the public ceremonies of the Inquisition itself. The annual proclamation of the edict of faith, for example, notified the faithful of an increasingly detailed catalogue of deviant behavior that was rejected by the Spanish Church and thus was to be reported. The list grew throughout the years: new heresies were included, and the actual description of the dogmas and practices they involved became more and more detailed. In fact, opponents of this list of heresies argued that its publication contributed precisely to the diffusion of heresy, instead of curbing it. ${ }^{93}$

The presence of the local elites-nobles, clergy, familiares-and the secular administration of a town or village-bailiff, city magistrates, judges-reinforced the idea of consensus within Spanish society. The sermons that were preached accompanying the proclamation of the edict were also powerful transmitters of religious norms and values, as they emphasized the individual and social consequences of (not) reporting deviant behavior: denouncing heresy not only relieved one's individual conscience, it also preserved society from divine wrath and from the annihilation of prosperity; not denouncing heresy equaled committing a deadly sin, punished with major excommunication, and damaged society as a whole. Since they were preached during Lent, their effect on the individual conscience of each inhabitant must have been important. ${ }^{94}$

The annual auto-da-fé in the capital of the district, which all inhabitantslocal authorities as well as local elites and common people-were obliged to attend, had the same effect, although on a smaller scale. Especially from 1561 onward, when inquisitor general Fernando de Valdés restructured their procedure and standardized their ceremony, autos-da-fé not only became a public demonstration of the power of the Holy Office, they increasingly confronted the public with the kind of deviant behavior that was to be punished, in particular through the proclamation of the individual sentences. ${ }^{95}$ On the other hand, the sermon at the beginning of every auto-da-fé highlighted the indispensable role of the Inquisition as the defender of Catholicism and preserver of the Commonwealth, and stressed the obligation of every Christian to cooperate with the tribunal. ${ }^{96}$ This message became even more obvious when, again from 1561 onward, several oaths to sustain and support the Inquisition as an instrument to eradicate heresy were actually included in the ceremony. First, the inquisitors presiding at the auto-da-fé would administer the oath to

93 Thomas, La represión, 53-54.

94 Villa Calleja, 'La oportunidad,' 312-313.

95 Kamen, The Spanish Inquisition, 205.

96 See also Edward Glaser, 'Invitation to Intolerance: A Study of the Portuguese Sermons Preached at auto-da-fé,' Hebrew Union College Annual 27 (1956): 327-385. 
the king-if present-or his representative, including viceroys and governors. The royal oath was followed by the oath of the local authorities, and by a collective oath of the people, read by a secretary of the institution. ${ }^{97}$ The sermon, the oaths, and the declaration of the sentences were probably the most effective components from the perspective of socialization.

Apart from these annual ceremonies, the faithful were continuously held responsible for the behavior of their acquaintances and even other people living nearby, especially in dependency relationships. In 16th-century Spain, heresy was not only the problem of the heretic, but also of the people surrounding him, and of society in its entirety. Thus, parish priests watched over the faith of their flock not only through the annual confession. Heads of family were also supposed to surveil the people living under their roof. Surveillance practices even went beyond family relationships. Employers controlled their work force, innkeepers and hospitals their guests and patients, landlords their tenants, and even benefactors the beggars they gave alms. The trials of the Inquisition contain lots of examples of people interrogating others about their religious practices and beliefs, especially after they found that they did not perform their religious duties or they gave public utterance to heterodox opinions about religious topics. ${ }^{98}$

Two instruments facilitated this type of informal control. The first one, the cédula de confesión ('certificate of confession'), was developed by the Council of Trent and was obligatory in the entire Catholic world. This document certified that one had complied with his or her obligation to confess before his or her parish priest at least annually. ${ }^{99}$ By requiring parishioners to give their annual confession, parish priests were able to actively detect heresy through the confessional, or, if the person in question did not comply, by interrogating him about why he had not. It also allowed them to surveil travelers, pilgrims, foreigners, beggars and vagrants traversing their parishes by asking them for their certificate. Innkeepers and hospitals were obliged to verify the certificates of their guests, and if they could not produce a valid specimen, not only were they denied access to the inn or the hospital, their names were passed on to the authorities. Moreover, local parish priests and bailiffs were obliged to inspect all inns and hospitals within their territory on a daily basis, before night fell. In order to prevent problems with the Inquisition, employers and landlords would require their employees and tenants to have one. There are

97 Bruno Aguilera Barchet, 'El procedimiento de la Inquisición española,' in: Pérez Villanueva \& Escandell Bonet, Historia, vol. 2, 507; Kamen, The Spanish Inquisition, 204-205.

98 Thomas, Los protestantes, 79-103.

99 Thomas, Los protestantes, 71-74. 
even examples of benefactors asking the beggar for his certificate before giving him alms. And if one moved to another town or village, he or she was obliged to show the certificate to the local parish priest on his or her arrival. ${ }^{100}$ Thus, the cédula de confesión became a kind of identity card of the good Catholic.

The second instrument was the papal Bula de la Cruzada (Bull of the Crusade). Having its roots in the 11th century as a contribution to the war against the infidels, it continued to exist after the fall of Granada in 1492, and the alms were used for other pious works, such as the construction of churches. The individuals buying the bull and simultaneously attending mass, confessing, fasting and receiving Holy Communion-which was a surveillance program on its own-were absolved of specific sins and censures, were granted commutation of specific vows they were not able to fulfil, and were allowed to eat eggs, milk, and cheese during Lent and on fast days. ${ }^{101}$ More important, refusing to buy the bull was considered a declaration of support for non-Catholic religions. Hence, a family head or a shop owner would buy a bull for each and every member of his family or workforce every year in order to avoid problems. They were held personally responsible for anyone of their people not having the bull, and they would be interrogated by the Inquisition. Sometimes, people were asked to show their bull, especially when doubts had arisen about their orthodoxy. ${ }^{102}$ Bula and cédula thus played a similar role in the mechanism of informal control.

An equally important aspect of the socialization process was stigmatization ('labelling activity'). By stigmatizing deviant behavior, the Inquisition defined a kind of no-go zone for the faithful, and not only stimulated people not to follow the example of the deviants, but to report similar behavior by others. During the 16th century, stigmatization grew in importance as part of the Inquisition's public ceremonies. Abjuration became a separate stage of the autos-da-fé. While before, every convict abjured immediately after the reading of his sentence, standing before the inquisitors, from about 1560 onward abjuration emerged as a specific item at the end of the ceremony, when a collective act of abjuration in small groups took place. For this purpose, there was even a separate platform developed, located right between the stands of the authorities and the convicts, and in front of the stand of the Inquisition, that is, at a central point of the whole scene of the autos-da-fé, and thus giving the public a much better view. ${ }^{103}$

\footnotetext{
100 Examples of such cases can be found in Thomas, Los protestantes, 73-77.

101 Antonio Ruiz de Salces, Explicación de la Bula de la Santa Cruzada (Madrid, 1881).

102 Examples in Thomas, Los protestantes, 77-79.

103 Bethencourt, The Inquisition, 277-281.
} 
The sentences that were read during an auto-da-fé also contained all deviant behavior a convict was accused of, and not only those charges he was found guilty of. Thus, the Inquisition made it appear that convicts were guilty of all charges. The vow of secrecy convicts had to make at the end of their trial stopped them from commenting on their sentence, which probably reinforced stigmatization. People that were found innocent, were not declared as such during an auto-da-fé, although this would have been the most effective-and also fair-way to restore their lost reputation. Instead, they were cleared of any incrimination during a private ceremony in the inquisitorial palace earlier on the day. ${ }^{104}$ The combination of all these elements confirms that the convicts were not the main focus of the autos-da-fé; the public attending the ceremony was. The crowd had to be socialized, and the individual fate of the convicts was subordinate for that purpose.

Once deviants were convicted, several instruments perpetuated stigmatization. From 1559 onward, reports of important autos-da-fé were printed and distributed. Sometimes they were restricted to the list of convicts that appeared before the inquisitors, on other occasions they also contained a full description of the ceremony, including the text of the sermon. Copies circulated in Spain and abroad; in fact, the Flemish engravings of the 1559 auto-da-fé in Valladolid were probably based on such accounts. ${ }^{105}$ Thus, these printed reports simultaneously combined the purposes of socialization and stigmatization alike.

The sambenito was another powerful instrument of stigmatization. It warned the local community that the wearer had been condemned for heresy. Curiously, the symbols depicted on it did not refer to the heresy the wearer was guilty of, but to the degree of culpability (light abjuration, strong abjuration, reconciliation, condemnation of the soul by death at the stake, relapse), thus creating one big category of heresy in which all deviant behavior was put at the same level. In general, the sambenito thus led to social isolation, as no rightminded Catholic wanted to be associated with heretics. Petitions of convicts to the Inquisition requesting the commutation of this punishment show that the sambenito was the main obstacle to finding a job, obtaining alms from the faithful, or even finding a spouse for their children. ${ }^{106}$ From Valdés' instructions onward, sambenitos also perpetuated stigmatization in the sense that after the wearer had served his sentence, they were hung on display in the convict's parish church in order to remind future generations that heresy had contaminated their line. At that time, the convict's name, place of birth, father's name

\footnotetext{
104 Thomas, Los protestantes, 96.

105 Bethencourt, The Inquisition, 291-294.

106 Thomas, La represión, 95-96.
} 
and, if the convict was a woman, her husband's name, their place of residence, the heresy for which the person was convicted, the punishment, and the year the sentence was passed were written on the garment. ${ }^{107}$ Inquisitors and commissioners inspected these churches on a regular basis and made sure that no convict shirked this obligation. Moreover, when the text became illegible, sambenitos were regularly cleaned or, if necessary, replaced with a new specimen, even if the convict had died decades or even centuries before. ${ }^{108}$

Stigmatization was also achieved and perpetuated by the so called inhabilidad ('inability'), which was already defined by the instructions of Torquemada and Deza. Once reconciled, convicts as well as their offspring for two generations were subjected to a series of restrictions, including not being permitted to hold public offices, to join a religious order, to practice as tax farmers, physicians, pharmacists or barber-surgeons, to carry arms or ride on horseback, to wear jewels made of gold, silver, pearls, or coral, and to dress in silk. ${ }^{109}$ Hence, the inhabilidad perpetuated the infamous memory of heretics through their offspring.

All these efforts led to a society in which popular, informal surveillance became a normal part of social interaction. Trials from 1560 onward testify to the eagerness of at least the orthodox, in general Old Christian, part of Spanish society to participate in the preservation of Catholicism by collaborating with the Inquisition in its struggle against heterodoxy. In the case of foreigners, for example, testimonies of witnesses show how in particular French, British, Flemish, and German subjects were time and again interrogated by local parish priests, innkeepers, bailiffs, employers, fellow travelers, children playing in the street, landlords, fellow tenants, et cetera, about their faith, even if they did not give cause for suspicion at all. It is therefore no surprise that most of the denunciations did not come from members of the Inquisition (comisarios, familiares), and not even from members of the clergy, but from ordinary people, including wives accusing their husbands. In the case of Protestant convicts, for example, more than 80 per cent of all denunciations were made by family members, acquaintances, fellow workers or other persons from the environment of the accused. ${ }^{110}$

\footnotetext{
107 The Museo Diocesano of Tui preserves the only samples of genuine sambenitos. Cf. Jesús Casas Otero, Los sambenitos del Museo Diocesano de Tui (Tui, 2004).

108 Bethencourt, The Inquisition, 288.

109 Bennassar, L'Inquisition, 132-134; Bernardo López Belinchón, 'La memoria de la infamia,' in Actas del Congreso Internacional Felipe II (1527-1598). Europa y la Monarquía católica, (ed.) José Martínez Millán (Madrid, 1998), vol. 3, 271-289. 
The adaptations described so far allowed the Inquisition to reorient its activities during the 16th century from the Judaism of conversos towards other kinds of deviating that had manifested themselves on the Iberian Peninsula. The first group to suffer inquisitorial persecution were the alumbrados (or illuminists), adherents of a current of local mysticism that propounded a direct relationship between the faithful and God, stating that God revealed the correct interpretation of the Scriptures in the hearts of people without the intervention of the clergy. The Inquisition started persecution in 1524 and issued its first edict against the movement in 1525 . In the 1530 s the movement was completely rooted out. 111

The alumbrados were soon followed by the supporters of Erasmus and his northern spirituality. Erasmus' writings spread rapidly and were a huge success after the return of the court in 1522, which was the focal point of Erasmianism in Spain. Among his admirers, most of them humanists and scholars, were dignitaries as important as the King's Grand Chancellor Mercurino di Gattinara, the Archbishop of Toledo Alonso de Fonseca, and the Inquisitor General himself, Alonso Manrique de Lara-although the Council of the Inquisition consisted of anti-Erasmians. ${ }^{12}$ The more traditional sectors of society, headed by the royal secretary and future head of the Council of State Francisco de los Cobos, and supported by the Dominican and Franciscan orders, rejected Erasmus' model of a less formal and more spiritual faith. ${ }^{113}$ In 1527 , they organized a conference in Valladolid intended to condemn the writings of the Dutch humanist, but they did not succeed. It was not until 1529, when the court left Spain, taking Gattinara and the most important defenders of Erasmus with it, and Alonso Manrique was subsequently removed from power by his enemies, that persecution of Erasmianism broke out. By 1540, Erasmianism was eliminated, and a few years later the works of Erasmus were placed on the index.114

The third religious movement that became a target of the Inquisition's new policy was luteranismo, a generic term for all kind of Protestant ideas. From the beginning of Luther's reform, Protestant writings reached Spain and were very successful among conversos. By 1525, the Inquisition issued an edict that prohibited the possession and reading of Luther's works. Notwithstanding,

111 Bernardino Llorca, La Inquisición española y los alumbrados (1509-1663) (Salamanca, 1980); Antonio Márquez, Los alumbrados, (Madrid, 1980).

112 On Manrique de Lara, see : H. Pizarro Llorente, 'Manrique de Lara, Alonso,' in Prosperi, Dizionario, vol. 2, 973-974.

113 Cf. Marcel Bataillon, Érasme et l'Espagne (Geneva, 1937).

114 Miguel Avilés Fernández, Erasmo y la Inquisición (Madrid, 1980). 
Spanish Protestants were increasingly associated with alumbradismo and Erasmianism, and many of them were persecuted on the basis of a combination of accusations. ${ }^{115}$

The changes in the Inquisition's prosecution policy seem to have occurred abruptly; however, they came about rather gradually. In fact, behind these new heresies, the Holy Office usually descried the work of Jews, conversos, and their protectors and supporters, and their doctrines were regarded as new manifestations of an old threat, namely Judaism. Many alumbrados, Erasmians and Spanish luteranos were indeed New Christians. In this respect it is striking that Spanish Protestants with Jewish ancestors were interrogated much more intensively and spent much more time in prison-even if their luteranismo was hardly elaborated-than foreign Protestants mastering all aspects of Luther's doctrine. ${ }^{116}$

The social status of the members of these movements was equally important: they generally belonged to the intellectual elites, held offices at court, in the royal administration or in the church, were protected by members of the Castilian aristocracy, and were supported by the Franciscan order, which had chosen the side of the rebels during the Revolt of the Comuneros. Politically, they belonged to the court factions and the sectors in society that had sympathized with the comuneros or had even participated in the rebellion. In general, they were fierce opponents of the Inquisition. By eradicating these movements, the Inquisition was not so much responding to new religious currents in society, but was eliminating old political enemies. ${ }^{117}$

The discovery of the Protestant groups of Valladolid and Seville in $155^{8}$ at first reinforced this interpretation of Protestantism as a method developed by Jews in order to destabilize Catholicism. Many of the Spanish Protestants were indeed New Christians. However, the series of autos-da-fé organized between 1559 and 1562 in order to eradicate Spanish Protestantism informed the population. Soon, testimonies against other Spanish, and above all, foreign Protestants increased spectacularly, alerting the Inquisition to the problem of the infiltration of Protestantism via books and travelers. In the statistics of the Inquisition, foreign Protestants gained the upper hand over Spanish luteranos not later than $1563 .{ }^{118}$ Suddenly, Protestantism was no local problem of conversos anymore, but acquired international dimensions. What followed was a

115 Augustin Redondo, “Les premiers 'illuminés' castillans et Luther," in Aspects du libertinisme au XVIe siècle (Paris, 1974), 85-92.

116 Thomas, La represión, 173-189.

117 Martínez Millán, 'Las élites,' 103-167.

118 Thomas, La represión, 259. 
fierce persecution by all tribunals of the Inquisition on the Iberian Peninsula. Between 1559 and 1575, the Holy Office started more than 1500 trials for luteranismo, and burnt almost 80 per cent of all Protestants who were condemned to the stake in the period before 1648. Persecution slightly decreased between 1575 and 1585 (only 313 individuals were convicted), but when war broke out, first with England, then with France, the number rose again to 487, and until the end of the century, Protestants would keep on showing up in almost all autos-da-fé of Iberian tribunals.

Persecution of foreign Protestants only stopped after the conclusion of the agreement with the Hanseatic League (1597), the Treaty of London with England (1604), and the Treaty of Antwerp with the Dutch rebels (1609), all of them including arrangements on religious tolerance in Spain. After 1621, foreign Protestants were only persecuted during war time, and even then the Inquisition did not actively trace them. Peace treaties ending war, such as the Treaty of Madrid (1630), and especially the Treaty of Munster (1648), restored religious tolerance agreements. From 1648 onward, the Inquisition persecuted almost no Protestants. ${ }^{119}$

In the aftermath of the 1558 discovery, the Inquisition likewise systematized the censorship of books. Between 1520 and 1554, the Holy Office acted against the introduction and sale of heretical books in Spain-licenses to print books were the competence of the Council of Castile-by means of special edicts that were sent to the tribunals, and subsequently by re-editing catalogues of forbidden books published elsewhere, in particular those elaborated by the University of Leuven in 1546 and $1550 .{ }^{120}$ In 1559, however, Inquisitor General Fernando de Valdés produced the first Spanish Index librorum prohibitorum, followed by the Index of inquisitor general Gaspar de Quiroga in 1583 and 1584. They became the basis of inquisitorial censorship of printed material. The catalogues of 1612,1632 , and 1640 were merely revisions incorporating new works. ${ }^{121}$

In the 1560 , the confessionalization process initiated by Philip II also ended lenience towards moriscos. In 1566, the forty year transition period that the Granada moriscos had obtained after several short stages of persecution since 1502, expired. Instruction campaigns in the Christian religion were organized, and in 1567 all Muslim cultural traditions were prohibited, including the use of Arabic. The tribunal of Granada started persecution. The next year, a rebellion

119 Werner Thomas, 'The Treaty of London, the Twelve Years Truce and religious toleration in Spain and the Netherlands (1598-1621),' in The Twelve Years Truce (1609): Peace, Truce, War and Law in the Low Countries at the Turn of the 17th Century, (ed.) Randall Lesaffer (Leiden, 2014), 277-297.

120 Martínez Millán, La Inquisición española, 285-287.

121 Pinto Crespo, Inquisición, 149-234. 
broke out. In 1571, the moriscos were defeated and subsequently dispersed over the cities of Southern Castile in the hope that this would break their resistance to religious integration. This policy failed, and the Castilian tribunals of the Inquisition were now also confronted with rising numbers of moriscos being accused of preserving their old faith. In Aragon, and in particular in Valencia, the conflict was less violent, due to the resistance to coercive methods by the local aristocracy that needed the Morisco workforce. However, the tribunals of Valencia, Zaragoza, and Murcia also increased their prosecution of moriscos in the final decades of the 16th century. Finally, the moriscos were expelled from the Iberian Peninsula in 1609, a decision taken at least in part to compensate for the peace treaty with the Dutch rebels. ${ }^{122}$

The inquisition activity that most attests to the development of the institution into a Counter Reformation device was without any doubt the repression of deviant behavior among Old Christians. In general, the religious crimes they committed involved blasphemy and heretical propositions, and sexual offenses, all of which the Inquisition started persecuting following the decrees of the Council of Trent. ${ }^{123}$ Blasphemy and heretical propositions included the denial of God, disrespect to the Virgin Mary and the saints, rejection of the power of the sacraments, and criticism of the pope and the church. From 1560 up to 1614, they accounted for 35 per cent of all trials brought before the tribunals of the Inquisition. Numbers rose spectacularly between 1560 and 1590, and then decreased rapidly, attesting to the success of the inquisitorial campaign. ${ }^{124}$

Sexual offenses in the first place included bigamy. Although this crime was within the competence of royal courts, the Spanish Inquisition sporadically punished bigamous practices from at least 1521 onward. However, before 1560 it did so with leniency. When royal legislation in the 1540 s made punishment more severe, and Philip II, following the regulations of the Council of Trent issued in 1562 and 1563 , increased the penalty to ten years in galleys, the Inquisition also harshened its policy. Bigamists were systematically sentenced to participate in public autos-da-fé, thus setting an example to others, and sent to the galleys. By 1573, the problem seemed solved. The Council of the Inquisition ordered the tribunals to soften their campaign, and the number of convicted bigamists decreased. ${ }^{125}$ From 1559 onward, several tribunals also started

122 Antonio Domínguez Ortiz and Bernard Vincent, Historia de los moriscos (Madrid, 1989).

123 Superstition, on the contrary, was never a priority of the Inquisition, while witchcraft concentrated around the case of Zugarramurdi in 1609-1610. Henningsen, The Witches' Advocate; Henningsen, The Salazar Documents, 3-13; Martínez Millán, La Inquisición española, 268-273; Rawlings, The Spanish Inquisition, 128-134.

124 Dedieu, 'Le modèle religieux,' 244-251.

125 Dedieu, 'La défense,' 313-338. 
to penalize the belief-not the act-that sexual relations outside marriage with mutual consent were not a sin (simple fornicación). In 1573 the Council of the Inquisition expanded persecution to all districts, and in 1574 the statement was included in the list of heresies proclaimed by the edicts of faith. Convicts were obliged to participate in public autos-da-fé and were whipped in their home town. Until the end of the century, simple fornicación represented up to 30 per cent of all inquisitorial activity. ${ }^{126}$ Homosexuality and bestiality formed part of the Inquisition's jurisdiction in the kingdom of Aragon-not in Castile-from 1524 onward, but were mostly related to cases of conversos or moriscos. Severe persecution did not start until 1560 in the case of homosexuality, and 1570 in that of bestiality. ${ }^{127}$ Finally, the jurisdiction over the sollicitatio ad turpiam, sexual harassment of a woman by her confessor during confession, shifted from the diocesan courts to the Inquisition in 1561 , and was intensively persecuted until the 1630 . $^{128}$

7

Conclusion

In less than a century, the Spanish Inquisition transformed from a rather improvised institution depending on local initiative, badly financed, oriented almost exclusively to one kind of deviant behavior, attacked by many enemies, and with a precarious future, to a well-organized machine with solid funding, stable and strict procedures, a diverse set of heresies to punish and, most importantly, the support of a large part of Spanish society. From an institution providing a solution to one particular socio-religious problem, it became an instrument that had the capacity to remodel Spanish society enforcing old norms and values, and imposing new ones.

From the 16oos onward, this omnipotence was slowly restricted. The fact that Philip II's view on religion converged with that of the Inquisition had placed the institution in a powerful position. When raison d'Etat started to dominate Spanish politics, and the religious policy of the Crown diverged from the Inquisition's, the Holy Office was put under strict control and became an instrument in the hands of the government that could be mobilized whenever it was necessary-the persecution of Portuguese conversos after the fall of Olivares-or demobilized when not-the restrictions on the prosecution of Protestants imposed by the international treaties with Protestant nations. From

\footnotetext{
126 Dedieu, 'Le modèle,' 318.

127 Bennassar, 'Le modèle,' 343-348.

128 Sarrión Mora, Sexualidad, 57-67, 73-107; Haliczer, Sexuality, 42-62.
} 
the 1630 on onward, war, social upheaval, the economic crisis causing a sharp decline of the Inquisition's revenues, and government restrictions on inquisitorial privileges further marginalized the Inquisition's role in Spanish society. After 1650, its activities, except for censorship, again concentrated on Judaism. The difference was that, because of the consolidation and subsequent expansion of its structures and power basis in the 16th century, the purpose of the Holy Office's existence was hardly questioned, allowing its survival until the 19th century. 